\title{
GROWTH ANDYIELDOFSEMI-HYDROPONIC BELL PEPPER UNDERDESALINATION WASTE-WATER AND ORGANIC AND MINERALFERTILIZATION ${ }^{1}$
}

\author{
FRANCISCO SILDEMBERNY SOUZA DOS SANTOS ${ }^{2}$, THALES VINICIUS DE ARAÚJO VIANA ${ }^{3}$, SOLERNE \\ CAMINHA COSTA ${ }^{4}$, GEOCLEBER GOMES DE SOUSA ${ }^{5}$, BENITO MOREIRA DE AZEVEDO ${ }^{3}$
}

\begin{abstract}
In a scenario of water scarcity in semiarid regions, it is imperative to design food production systems that use different sources of water. The waste of desaltersis a potential source, especially when combined with the hydroponics technique that includes the supply of nutrient solution as a source of water and nutrients. In addition, other techniques such as enhanced organic matter with biofertilizer can complement this low-quality water use strategy. Thus, the aim of this study was to analyze the possible dampening effect of biofertilizers in the open system of hydroponic culture of pepper owing to the increase in water salinity. The study was conducted at the Teaching Unit, Research and Extension, Federal Institute of Education, Science and Technology of Ceará, Limoeiro do Norte Campus. The experimental design was a factorial $5 \times 4$ randomized block for five saline water concentration sand three doses of biofertilizers and one control with mineral fertilizer, and four replicates totaling 80 experimental units with 3 plants per plot. The variables analyzed were number of fruits per plant, production, and length and width of the fruit. All production variables declined linearly with increasing salinity. In addition, the biofertilizer did not attenuate the deleterious effects of salinity as shown by the productivity data. The fertilization with mineral fertilizers produced greater yields, followed by application of $50 \%, 100 \%$, and $150 \%$ of the biofertilizer dose.
\end{abstract}

Keywords: Salt stress. Capsicumannuum L. Mineral nutrition.

\section{CRESCIMENTO E PRODUÇÃO DO PIMENTÃO SEMI-HIDROPÔNICO SOBREJEITO DE DESSALINIZADORES E FERTILIZAÇÃO ORGÂNICA E MINERAL}

\begin{abstract}
RESUMO - O rejeito de dessalinizadores surge como uma fonte alternativa, principalmente quando aliado à técnica da hidroponia e da adubação com fonte orgânica e mineral. Objetivou-se avaliar os efeitos do uso do rejeito da dessalinização em sistema semi-hidropônico do tipo aberto na produtividade de plantas de pimentão fertilizadas com adubo orgânico e mineral. A pesquisa foi conduzida em sistemasemi-hidropônico tipo aberto no IFCE, Campus Limoeiro do Norte, CE. O delineamento experimental foi o de blocos casualizados em esquema fatorial $5 \times 4$, referentes as diferentes concentrações de água salina $\left(0,5 ; 1,5 ; 3,0 ; 5,0 ;\right.$ e 7,5 dS m $\left.{ }^{-1}\right)$ e quatro formas de aplicações de fertilizantes na solução nutritiva $(\mathrm{F} 1=50 \%$ da dose recomendada; F2 $=100 \%$ da dose recomendada e F3 $=150 \%$ da dose recomendada com fonte orgânica e F4 $=100 \%$ da dose recomendada com fonte mineral, com 4 repetições. Foram analisadas as seguintes variáveis: número de folhas, altura de plantas, área foliar, número de frutos por planta, comprimento e largura do fruto e a produção. A forma de adubação F3 (150\% da dose recomendada com fonte orgânica) seguido da F4 (100\% da dose recomendada com fonte mineral) e da $\mathrm{F} 1$ ( $50 \%$ da dose recomendada com fonte orgânica) atenuaram o efeito deletério da água do rejeito salino no crescimento do pimentão cultivado em sistema semi-hidropônico. A forma de adubação F4 (100\% da dose recomendada com fonte mineral) proporciona maior desempenho produtivo da cultura do pimentão cultivada em sistema semi-hidropônico irrigada com água de rejeito salino.
\end{abstract}

Palavras-chave: Estresse salino. Capsicumannuum L. Nutrição mineral.

\footnotetext{
${ }^{*}$ Corresponding author

${ }^{1}$ Received for publication in $07 / 17 / 2018$; accepted in 08/15/2019.

Paper extracted from the doctoral thesis of the first author.

${ }^{2}$ Agronomy Sector, Instituto Federal de Educação, Ciência e Tecnologia do Ceará, Tabuleiro do Norte, CE, Brazil; sildemberny@ifce.edu.br - ORCID: 0000-0003-2389-5655.

${ }_{3}^{3}$ Department of Agricultural Engineering, Universidade Federal do Ceará, Fortaleza, CE, Brazil; thales@ufc.br - ORCID: 0000-0003-07226371, benito@ufc.br-ORCID: 0000-0001-7391-1719.

${ }^{4}$ Agronomy Sector, Instituto Federal de Educação, Ciência e Tecnologia do Ceará, Limoeiro do Norte, CE, Brazil; solerne@ifce.edu.br ORCID: 0000-0003-4012-6137.

${ }^{5}$ Institute of Rural Development, Universidade da Integração Internacional da Lusofonia Afro-Brasileira, Redenção, CE, Brazil; sousagg@unilab.edu.br - ORCID: 0000-0002-1466-6458.
} 


\section{INTRODUCTION}

Bell pepper is one of the ten crops of greater economic importance in Brazil (SEDIYAMA et al., 2009). The top producing region are the South-east (48.5\%), followed by the North-east (31.3\%), South (14.6\%), Center-west (4.8\%), and North $(0.8 \%)$ regions. In the North-east region, Ceará is the top producing state, accounting for $31.4 \%$ of the regional production, followed by Bahia (27\%) (IBGE, 2016).

The grow in global demand for consumptive use of water resources and the need to promote safety of food for human consumption have created as cenario where in more efficient agricultural production systems are essential(STEDUTO et al., 2012). One characteristic of the semiarid north-east of Brazil is thes carcity of water resources. Therefore, desalination of low-quality water is being performed in several localities; however, the effluents are highly saline (MORAES et al., 2014), which results in the considerable degradation of natural resources, including soil. Nevertheless, waste from the desalination processis a potential source of water for the production of food, thereby generating in comeandavoiding environmental contamination (SILVA et al., 2012).

A strategy for harnessing saline wastewater is the use of semi-hydroponic systems containing nutrient solutions for food production (SOARES et al., 2006).It is thus possible tomainta in saline levels within ranges that are compatible with crop salt tolerance by adequately monitoring and replacing or exchanging the nutrient solution and a chievelower water consumption by plants (SILVA et al., 2012).

Another strategy that has been studied is the use of organic and mineral fertilizers to mitigate saline stress. In a study with the bell pepper crop,
Nascimento et al. (2011) stated that biofertilizers induce osmotic adjustment and favor the absorption of water and nutrients in saline environments. Moreover, Oliveira et al. (2014) reported that high doses of nitrogen and the use of saline water reduced the agronomic efficiency of nitrogen in the aubergine crop.

The objective of the present study was to assess the yield of bell pepper plants grownin a semihydroponic system using the wastewater from desalination with organic and mineral fertilization.

\section{MATERIAL AND METHODS}

The study was conducted in a protected environment in the experimental area of the Teaching, Research and Outreach Unit (UEPE)of the Federal Institute of Education, Science and Technology of Ceará (IFCE), located in Chapada do Apodi, municipality of Limoeiro do Norte, CE.

The siteis located at an altitude of $151 \mathrm{~m}\left(05^{\circ}\right.$ $06^{\prime} \mathrm{S}$ and $\left.37^{\circ} 52^{\prime} \mathrm{W}\right)$. The mean annual temperatureis $28.5{ }^{\circ} \mathrm{C}$, relative air humidity is $62 \%$, and average annual rainfallis $772 \mathrm{~mm}$, concentrated between March and May, with the period between July and December being the dry season. The climate is of the BSw'h' semi-arid type, according to the Köppen classification; very hot, with maximum rainfall in Autumn.

The treatments with different levels of salinity (Table 2) were established based on the results of the physico-chemical analyses of the waste waters collected at the Catumbela site, in the municipality of Russas-CE (CA), and at the Bela Vista site, in the municipality of Limoeiro do Norte, CE (BV) (Table 1).

Table 1. Chemical analysis of desalterwastewater in Catumbela, municipality of Russas-CE (CA) and in Bela Vista, municipality of Limoeiro do Norte, CE (BV).

\begin{tabular}{|c|c|c|c|c|c|c|c|c|c|c|c|}
\hline \multirow{2}{*}{ SITE } & $\mathrm{Ca}^{2+}$ & $\mathrm{Mg}^{2+}$ & $\mathrm{Na}^{+}$ & $\mathrm{K}^{+}$ & $\mathrm{Cl}^{-}$ & $\mathrm{SO}_{4}{ }^{2-}$ & $\mathrm{HCO}_{3}^{-}$ & $\mathrm{CO}_{3}{ }^{2-}$ & $\mathrm{EC}$ & SAR & $\mathrm{pH}$ \\
\hline & & \multicolumn{6}{|c|}{$\operatorname{mmol}_{\mathrm{c}} \mathrm{L}^{-1}$} & \multicolumn{4}{|c|}{$\mathrm{dS} \mathrm{m}^{-1}$} \\
\hline $\mathrm{CA}$ & 23.6 & 9.73 & 6.86 & 1.71 & 24.31 & 1.02 & 4.9 & - & 9.97 & 1.68 & 7.5 \\
\hline BV & 4.94 & 5.87 & 11.89 & 1.18 & 18.65 & 0.08 & 1.39 & - & 3.13 & 5.11 & 7 \\
\hline
\end{tabular}

After determining the highest wastewater electrical conductivity (EC) $\left(9.97 \mathrm{dS} \mathrm{m}^{-1}\right)$ and based on the ECof the irrigation canal'swaterof the experimental area $\left(0.5 \mathrm{dS} \mathrm{m}^{-1}\right)$ and the percentages of canal water and wastewater, the EC values of the treatments were determined using the following equation.

$C E_{\text {FNAL }}=\frac{\left(C E_{\text {waste }} \times \%_{\text {waste }}\right)+\left(C E_{C A N A L} \times \%_{C A N A L}\right)}{100}$

Eq. 01 where: $F_{\text {final }}\left(\mathrm{dS} \mathrm{m}^{-1}\right)$ is the final electrical conductivity of the combined waters, $\mathrm{EC}_{\text {Waste }}\left(\mathrm{dS} \mathrm{m}^{-1}\right)$ is the electrical conductivity of the desalterwaste water, \%Wasteis the percentage of desalter waste water (dimensionless), $\mathrm{EC}_{\text {Canal }}$ is the electrical conductivity of the canal's water $\left(\mathrm{dS} \mathrm{m}^{-1}\right)$, and \% Canal is the percentage of canal water (dimensionless).

The sequential calculation of theEC of the irrigation water obtained from the salinity treatments is shown in Table 2. 
Table 2. Electrical conductivity of irrigation water from the salinity treatments.

\begin{tabular}{|c|c|c|c|c|c|}
\hline \multirow{3}{*}{ Treatment } & \multicolumn{4}{|c|}{ Irrigation water } & \multirow{3}{*}{$\begin{array}{c}\text { Saline solution } \\
\text { EC }_{\text {FINAL }} \\
\left(\mathrm{dS} \mathrm{m}^{-1}\right)\end{array}$} \\
\hline & \multicolumn{2}{|c|}{ Canal } & \multicolumn{2}{|c|}{ Waste } & \\
\hline & $\begin{array}{c}\mathrm{EC} \\
\left(\mathrm{dS} \mathrm{m}^{-1}\right)\end{array}$ & $\%$ & $\begin{array}{c}\mathrm{EC} \\
\left(\mathrm{dS} \mathrm{m}^{-1}\right)\end{array}$ & $\%$ & \\
\hline A1 & & 100 & & 0 & 0.5 \\
\hline A2 & & 90 & & 10 & 1.5 \\
\hline A3 & 0.5 & 75 & 9.97 & 25 & 3 \\
\hline A4 & & 50 & & 50 & 5 \\
\hline A5 & & 25 & & 75 & 7.5 \\
\hline
\end{tabular}

The experimental design comprised a $5 \times 4$ factorial arrangement of randomized blocks corresponding to the different levels of water salinity $\left(0.5,1.5,3.0,5.0\right.$, and $\left.7.5 \mathrm{dS} \mathrm{m}^{-1}\right)$ and four fertilization regimes applied to the nutrient solution ( $F 1=50 \%$ of the recommended dose, $\mathrm{F} 2=100 \%$ of the recommended dose, $\mathrm{F} 3=150 \%$ of the recommended dose with organic fertilizer, and $\mathrm{F} 4=$ $100 \%$ of the recommended dose with com mineral fertilizer(TRANI; TIVELLI; CARRIJO, 2011). The design included four replicates and three plants were used per experimental unit.

Mineral fertilization was performed manually using the nutrient solution recommended by Trani, Tivelli e Carrijo (2011) for the bell pepper crop. The composition of the nutrient solution was that proposed by Guimarães (2013), i.e., N (9.5 g/plant), P (7.5 g/plant), and K (5 g/plant).

A semi-hydroponic system was used in the experiment. Each plant was placed in an18-L plastic pot containing inert substrate comprising charred rice husk from the local beneficiation industry, and standard processed coconut fiber, at a 1:1 ratio. A 5$\mathrm{cm}$ layer of gravel no.1 was placed on the bottom of the pots and covered with a polyethylenesheettokeep the substrate separate and there by promote the drain a ge of excessive solution.

The solutions were supplied using a motor pump for each salinity level. Each pump supplied enough solution to irrigate 48 pots, corresponding to 16 plots of the experiment (four plots per block). The solutions were supplied by self-compensating drippers at a flow rate of $4 \mathrm{~L} \mathrm{~h}^{-1}$ for each pot.

The All Big variety of bell pepper (Capsicumannuum L.) was used. The seeds were sowninexpandedpolystyrenetrayswith 128 cells filled with commercial substrate (vermiculite + coconut fiber). The seedlings were transplanted at approximately $30 \mathrm{~d}$ after sowing and were appropriately staked to provide adequate support.

The biofertilizer was prepared by anaerobic fermentation of fresh manure and water at a ratio of $50 \%(\mathrm{v} / \mathrm{v})$, for a period of $30 \mathrm{~d}$, in a hermetically sealed 240-L plastic container. To achieve the anaerobic system, the mixture was placed in a plastic container, leaving an empty space of 15 to $20 \mathrm{~cm}$ in the upper part of the container. A hose was fitted to the lid, with the opposite end dipped in a container with $20 \mathrm{~cm}$ of water for the outlet of gases (SILVA et al., 2016).

Nutrient content in the different biofertilizers is shown in Table 3 .

Table 3. Composition of essential macro- and micronutrients of the biofertilizer.

\begin{tabular}{lllllllllll}
\hline \multicolumn{1}{l}{ Chemical characteristics } & \multicolumn{10}{l}{} \\
\hline $\mathrm{N}$ & $\mathrm{P}$ & $\mathrm{K}$ & $\mathrm{Ca}$ & $\mathrm{Mg}$ & $\mathrm{S}$ & $\mathrm{Na}$ & $\mathrm{Fe}$ & $\mathrm{Cu}$ & $\mathrm{Zn}$ & $\mathrm{Mn}$ \\
\hline$\left(\mathrm{g} \mathrm{L}^{-1}\right)$ & & & & & & & & & $\left(\mathrm{mg} \mathrm{L}^{-1}\right)$ & \\
\hline 1.59 & 0.32 & 0.01 & 1.58 & 0.59 & 0.01 & 92 & 425.10 & 4.28 & 15.60 & 21.80 \\
\hline
\end{tabular}

Plant height was measured at $61 \mathrm{~d}$ after transplantation (DAT) using a 100-cmrulerfrom the base to the apical area of the plant. The number of leaves was obtained by counting the fully expanded leaves. Leaf area was determined using Equation 2 proposed by Tivelli, Mendes and Goto (1997) with the values of leaf length and width that were obtained with a $30-\mathrm{cm}$ ruler.

$$
A=L \times W \times F c \times 0.81
$$

where: $\mathrm{A}=$ leaf area $\left(\mathrm{cm}^{2}\right) ; \mathrm{L}=$ leaf length $(\mathrm{cm}) ; \mathrm{W}=$ leaf width $(\mathrm{cm}) ; \mathrm{Fc}=$ correction factor (dimensionless; 0.81).

Three fruit collections were performed. The first, second, and third collections were performed at 95, 105, and 112 DAT, respectively. The collected fruits were subsequently weighed using digital scales $(0.001 \mathrm{~g}$ accuracy) and the following parameters were assessed: number of fruits per plant, yield (Y), represented by the mean production of fruits per pot (g/plant) accumulated in the different collections, and fruit diameter and length measured with a digital pachymeter. 


\section{RESULTS AND DISCUSSION}

Analysis of variance showed a significant effect $(p<0.05)$ of salinity factors and fertilization regimes(organic and mineral) on the variables number of leaves, plant height, and leaf área (Table 4).

Table 4. Mean square values of the variables number of leaves (NL), plant height (PH),leaf area (LA) of bell pepper under saline stress and different fertilization regimes.

\begin{tabular}{ccccc}
\hline FV & GL & NL & PH & LA \\
\hline Salinity (S) & 4 & $0.3905^{\text {ns }}$ & $1.6165^{\text {ns }}$ & $3.2263^{*}$ \\
\hline Fertilization regime (FR) & 3 & $1.5066^{\text {ns }}$ & $0.3990^{\text {ns }}$ & $0.3538^{\text {ns }}$ \\
\hline Interaction (S $\times$ FR) & 12 & $2.2191^{*}$ & $7.5533^{* *}$ & $1.9914 *$ \\
\hline Blocks & 3 & $12.8^{* *}$ & $1.49^{\text {ns }}$ \\
\hline Residual & 57 & & $12.922^{\text {ns }}$ \\
\hline Total & 79 & & 22.39 \\
\hline CV $(\%)$ & - & 30.77 & \\
$* *$ significant at $1 \%$ probability; $*$ significant at $5 \%$ probability; ${ }^{\text {ns }}$ not significant. &
\end{tabular}

There was a considerable reduction in the number of leaves with increasing salinity of irrigation water in all fertilization regimes, with $\mathrm{F} 4$ and F5 being the most effective in mitigating the effect of saline stress (Figure 1). Saline stress had a negative effect on leaf formation, resulting in reduced photosynthesis because an increase in salt concentration reduces production, accumulation, and distribution of vital photoassimilates in plants (GOMES et al., 2015). Lemos Neto et al. (2012) also observed a reduction in the number of leaves in bell pepper plants irrigated with saline water.

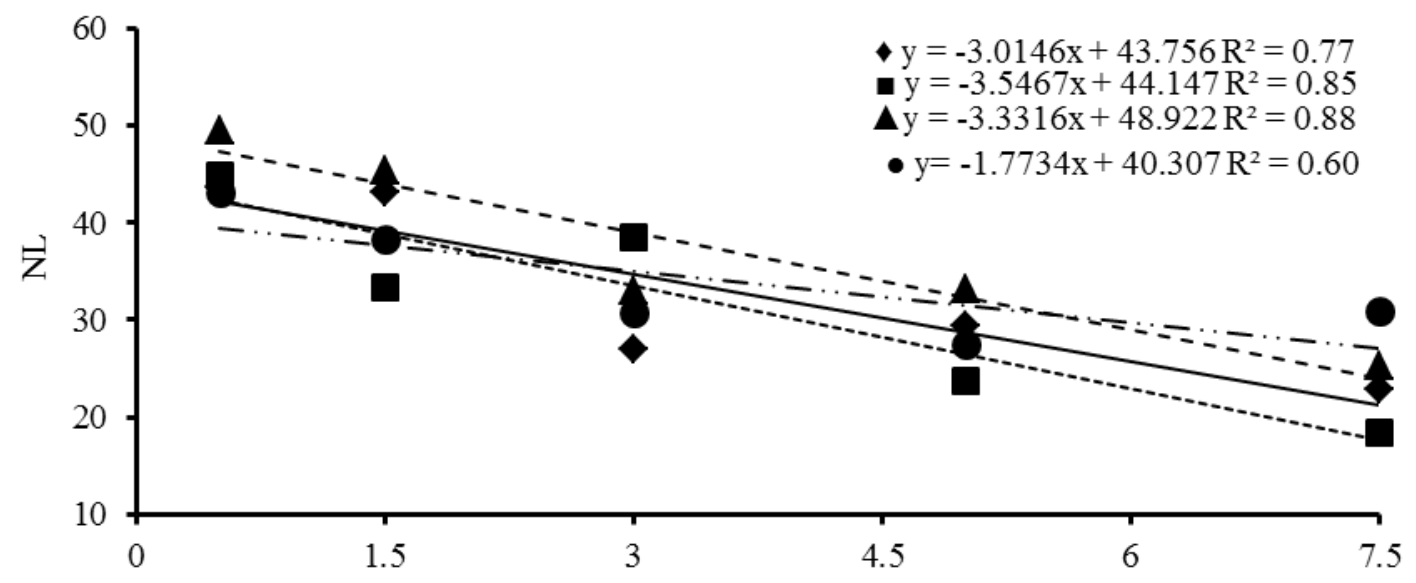

Electrical conductivity of water- $\mathrm{ECw}\left(\mathrm{dS} \mathrm{m} \mathrm{m}^{-1}\right)$

Figure1. Number of leaves in bell pepper plants under different levels of salinity of irrigation water and different

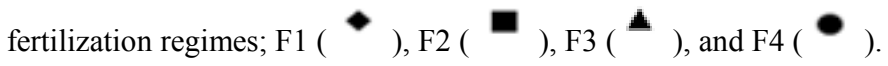

Campos and Cavalcante (2009) used bovine biofertilizer as organic fertilizer in bell pepper crop and their results were similar to those presented herein. Mitigation by this organic fertilizer in saline environments has been described by Gomes et al. (2015) in the sunflower crop and by Sousa et al. (2016) in ther a dish crop. Guedes Filho et al. (2013) assessed a sunflower crop irrigated with saline water and fertilized with nitrogen and obtained a reduction in the number of leaves without the positive effect of nitrogen use.

Regression analysis showed a linear decreasing model for plant height as a function of saline stress under different regimens of fertilization (Figure 2). F1 resulted in greater plant height than the other fertilization regimes. Saline stress limits plant growth because the increase in environmental osmotic pressure and reduction in readily available water affects plant cell elongation (SILVA et al., 2013). 


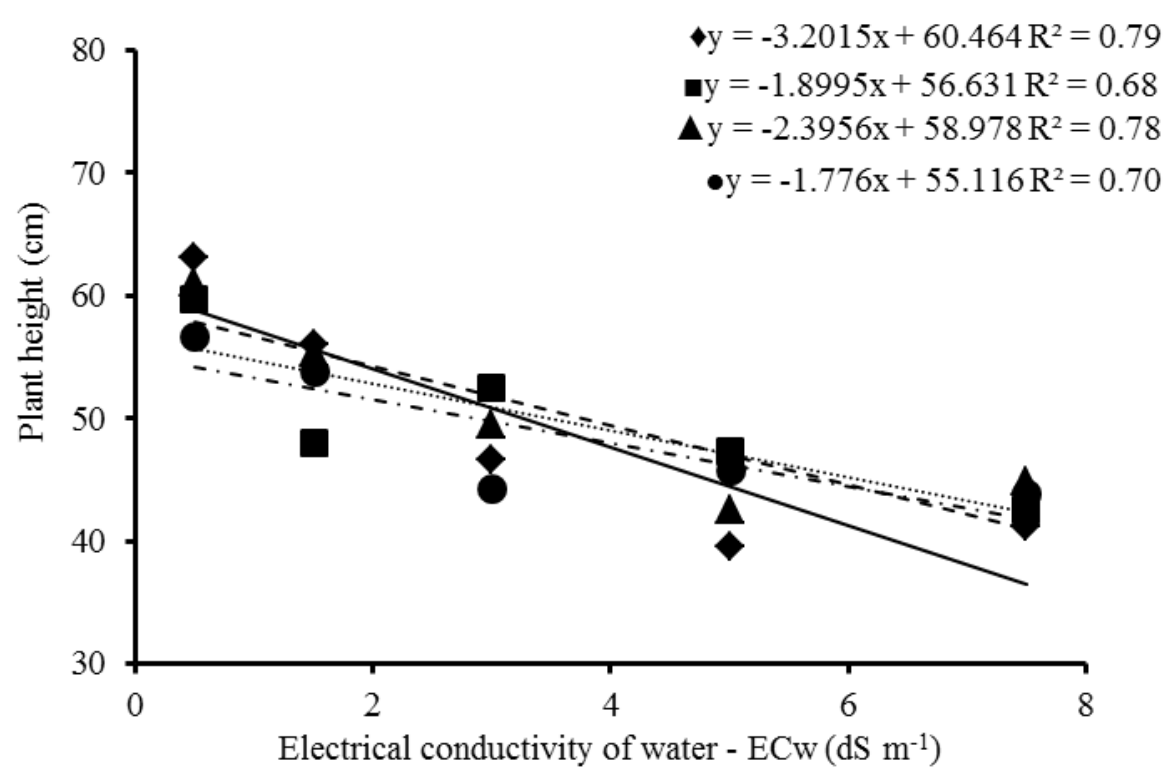

Figure 2. Height of bell pepper plants under different levels of salinity in irrigation water and different fertilization regimes;

$\mathrm{F} 1(\bullet), \mathrm{F} 2($

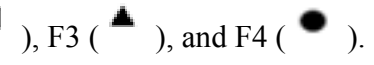

Consistent with the results presented herein, Lemos Neto et al. (2012) reported a considerable reduction in the height of bell pepper plants with increasing salinity. Cavalcante et al. (2011) applied bovine biofertilizer to a physic nut crop irrigated with saline water and reported similar responses in plant height as those presented herein. Results were also consistent with those reported by Gomes et al. (2015) for an irrigated sunflower crop in soils with crab biofertilizer. However, Guedes Filho et al. (2013) did not observe a significant effect of the interaction between salinity and nitrogen on plant height in the sunflower crop.

Increased salt concentration in irrigation water inhibited the leaf area of bell pepper plants. This increase was less marked when fertilization regimes F4 and F2 were used, as shown by the decreasing linear model (Figure 3). This may be explained by the availability of nutrients to the plants from the beginning of the cycle. Thus, F1 and F2 did not lead to considerable leaf area.

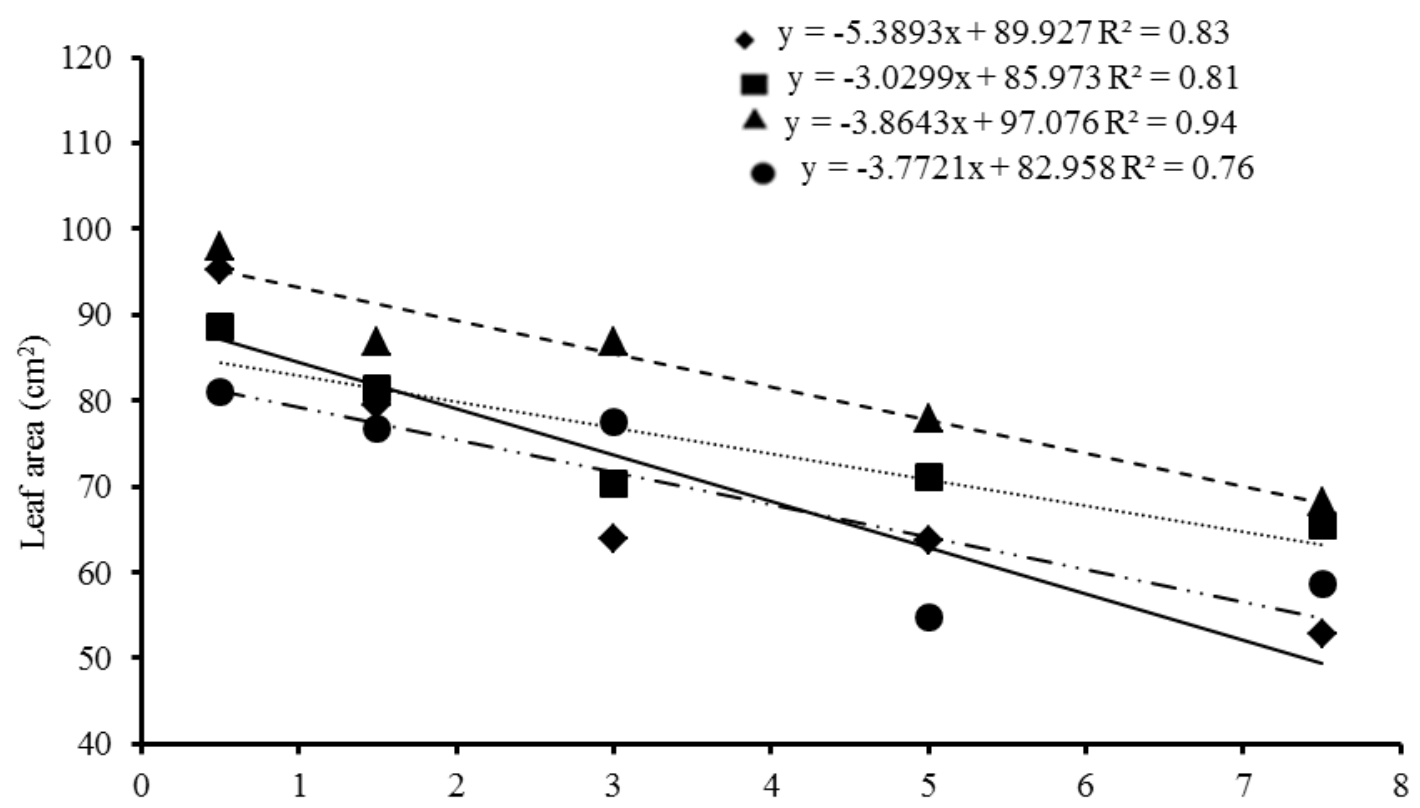

Electrical conductivity of water - $\mathrm{ECw}\left(\mathrm{dS} \mathrm{m} \mathrm{m}^{-1}\right)$

Figure 3. Leaf area of bell pepper plants under different levels of salinity in irrigation water and different fertilization regimes; F1 $(\bullet)$ ),F2 $(\boldsymbol{\bullet}), F 3(\boldsymbol{\Delta})$, and F4 $(\bullet)$ ).

Rev. Caatinga, Mossoró, v. 32, n. 4, p. 1005 - 1014, out. - dez., 2019 
Nunes et al. (2013) evaluated the effect of nutrient solution salinity on a bell pepper crop grown in a hydroponic system and observed a reduction in leaf area at 85 DAT. Sousa et al. (2016) used bovine biofertilizer in a radish crop irrigated with saline water and demonstrated a reduction in leaf area, which was less marked in the treatments with organic fertilizer. In contrast, Lima et al. (2014) analyzed the interaction between mineral fertilization with nitrogen and saline stress in the castor-oil crop and did not observe an attenuating effect of the mineral element on leaf area.

According to the results of the analysis of variance (Table 5), there was a significant effect of the interaction between salinity and fertilization regimes (organic and mineral) on thenumber of fruits per plant, fruit length, fruit diameter, and yield.

Table 5. Summary of analysis of variance for the variables yield (Y), number of fruits per plant (NFPP), fruit length (FL), and fruit diameter (FD) in the bell pepper crop under saline stress and different fertilization regimes.

\begin{tabular}{|c|c|c|c|c|c|}
\hline $\mathrm{FV}$ & GL & NFPP & $\mathrm{FL}$ & $\mathrm{FD}$ & $\mathrm{Y}$ \\
\hline & & - & $(\mathrm{mm})$ & $(\mathrm{mm})$ & $\mathrm{g} /$ plant \\
\hline Salinity (S) & 4 & $7.4719 * *$ & $8.0150 * *$ & $11.1119 * *$ & $4.3771 * *$ \\
\hline $\begin{array}{c}\text { Fertilization } \\
\text { regimens }(\mathrm{FR})\end{array}$ & 3 & $3.2533^{*}$ & $1.4305^{\mathrm{ns}}$ & $5.6907 * *$ & $0.3289^{\mathrm{ns}}$ \\
\hline $\begin{array}{c}\text { Interaction }(\mathrm{S} \times \\
\mathrm{FR})\end{array}$ & 12 & $8.3164 * *$ & $3.6170 * *$ & $7.1189 * *$ & $3.6123 * *$ \\
\hline Blocks & & 2.228 & 1.35 & 7.11 & 31.22 \\
\hline Residual & 57 & & & & \\
\hline Total & 79 & & & & \\
\hline CV (\%) & & 25.53 & 12.78 & 11.07 & 48.07 \\
\hline
\end{tabular}

$* *$ significantat $1 \%$ probability $(p<0.01) ;{ }^{*}$ significant at $5 \%$ probability $(0.01 \leq p<0.05) ;{ }^{\text {ns }}$ not significant $(p \geq 0.05)$.

Saline stress affected the number of fruits per plant; however, its influence was less marked in F1 and F4 fertilization regimes (Figure 4). At the higher level of salinity, mineral fertilization and F1 favored the increase in the number of fruits per plant.

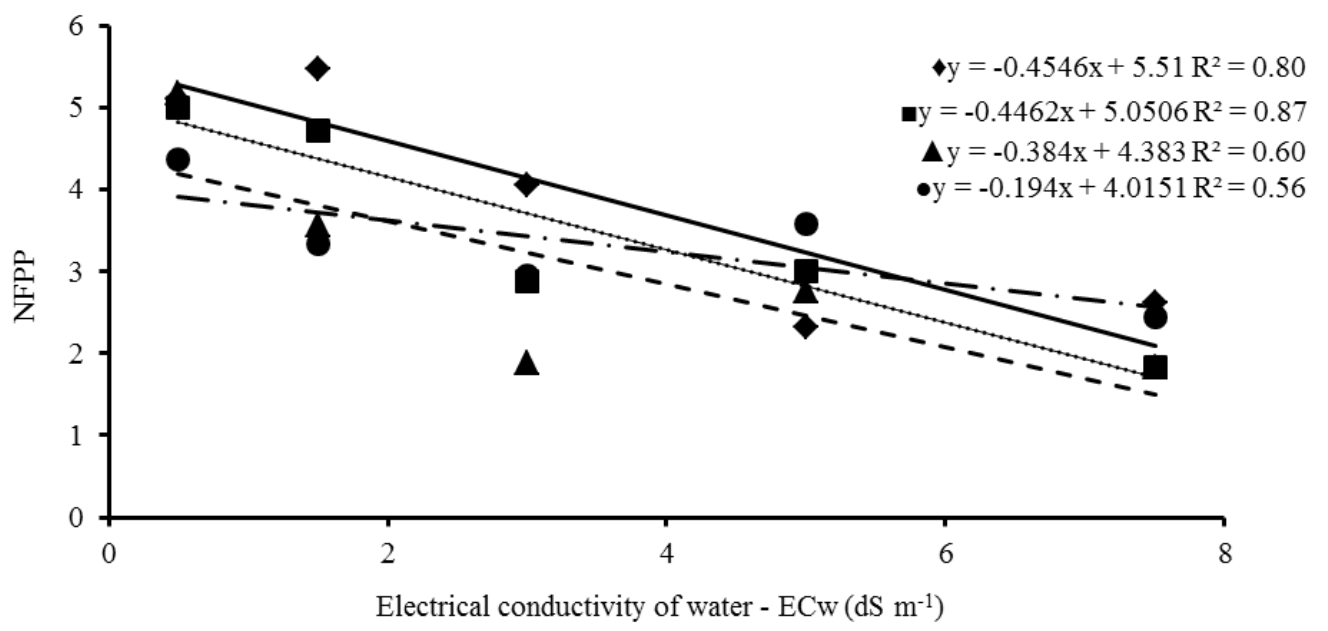

Figure 4. Number of fruits per plant in the bell pepper crop under different levels ofsalinity in irrigation water and different fertilization regimes; F1

Ünlükara, Kurunç and Cemek (2015) and Medeiros et al. (2012) have shown the same trend in the bell pepper crop and in the tomato crop, respectively. However, Rubio et al. (2011) obtained different results, i.e., they did not observe the influence of salinity on the total number of fruits per bell pepper plant. Similarly, Leonardo et al. (2007) did not detect a beneficial mitigating action of organic matter on the deleterious effect of salinity. In this study, bell pepper was grown at a salinity of 1.5 to $6.0 \mathrm{dS} \mathrm{m}$. Salinity alone had a significant effect on the number of fruits per plant, whereas its

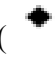
), F2 ( ), F3 ( ), and F4 (

interaction with organic matter did not.

Regression analysis showed a decreasing linear model for fruit growth with increasing electrical conductivity of irrigation water for all treatments (Figure 5); however, mineral fertilization was more effective in mitigating the effect of saline stress than the other regimes. The effect of the interaction between salinity and fertilization regimes with biofertilizer may be explained by the high ECof the biofertilizer combined with the ECof the solution, which probably prevented greater fruit growth. 


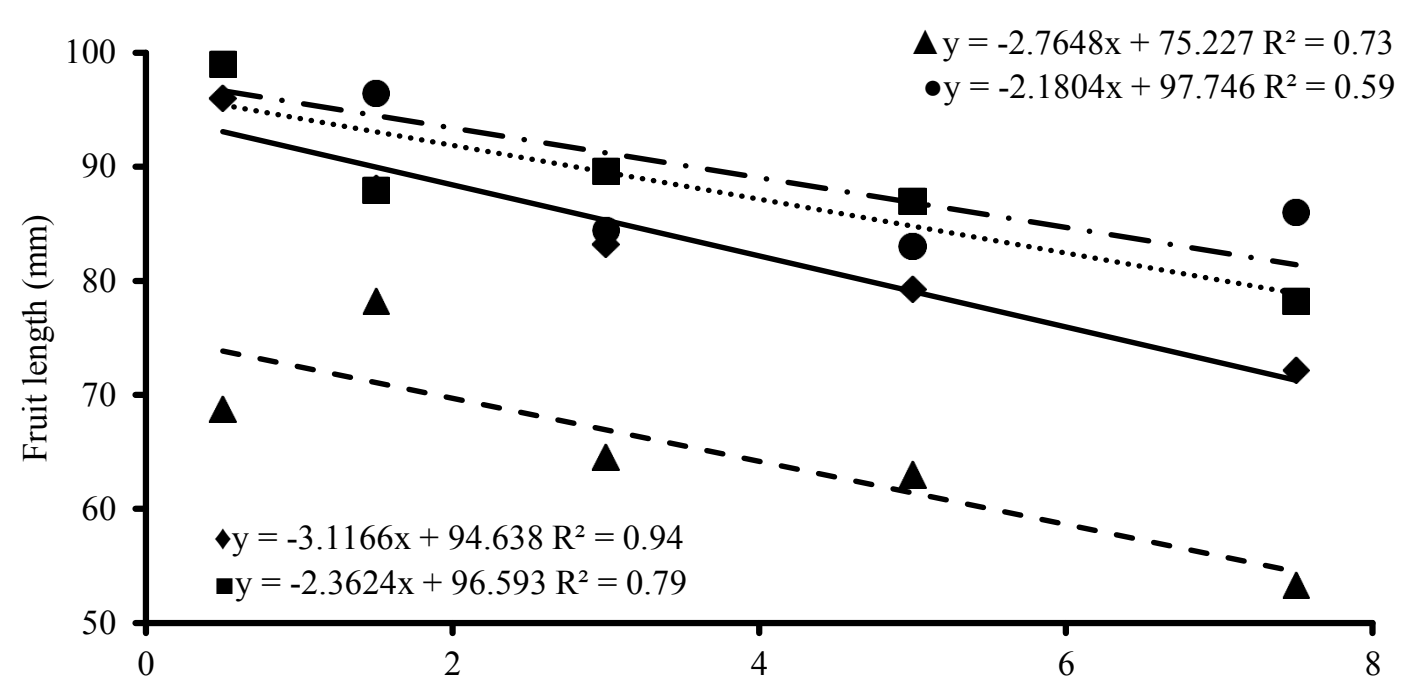

Electrical conductivity of water- $\mathrm{ECW}\left(\mathrm{dS} \mathrm{m} \mathrm{m}^{-1}\right)$

Figure 5. Fruit length in bell pepper cropunder different levels ofsalinity in irrigation water and different fertilization

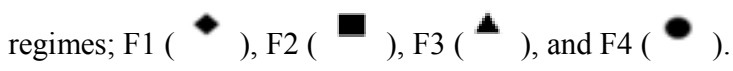

According to the Mercosul regulations (2016) adopted in Brazil, the length of commercial bell peppers is $\geq 50 \mathrm{~mm}$ and fruits are considered small, average, and large when fruit length is $50-80 \mathrm{~mm}, 80$ $-100 \mathrm{~mm}$, and $>100 \mathrm{~mm}$, respectively. Therefore, fruits in all treatments were included in the commercial category, with fruits in treatmentF3 being classified as small and the remaining fruits being classified as average, with the exception of fruits in F1 starting from a salinity of $5 \mathrm{dS} \mathrm{m}^{-1}$.

Oliveira et al. (2014) observed a positive effect of irrigation water with salinity up to 2.48 (dS $\mathrm{m}^{-1}$ ) on fruit length and a reduction at higher salinity levels, i.e., the lowest length value was obtained at the highest salinity level. With regard to organic fertilizers, Dias et al. (2012) analyzed the influence of irrigation with saline water in a soil with bovine biofertilizer and reported a similar finding for this variable.

Like fruit length, fruit diameter was inversely related to the increase in salinity of irrigation water (Figure 6); however, the performance of the mineral fertilizer was superior to that of the other regimens. This result reflects the mobility and form of application of the chemical fertilizer, i.e., the mineral elements move more rapidly from the solution in the soil to the roots and to the fruits than organic fertilizers (SANTOS et al., 2017).

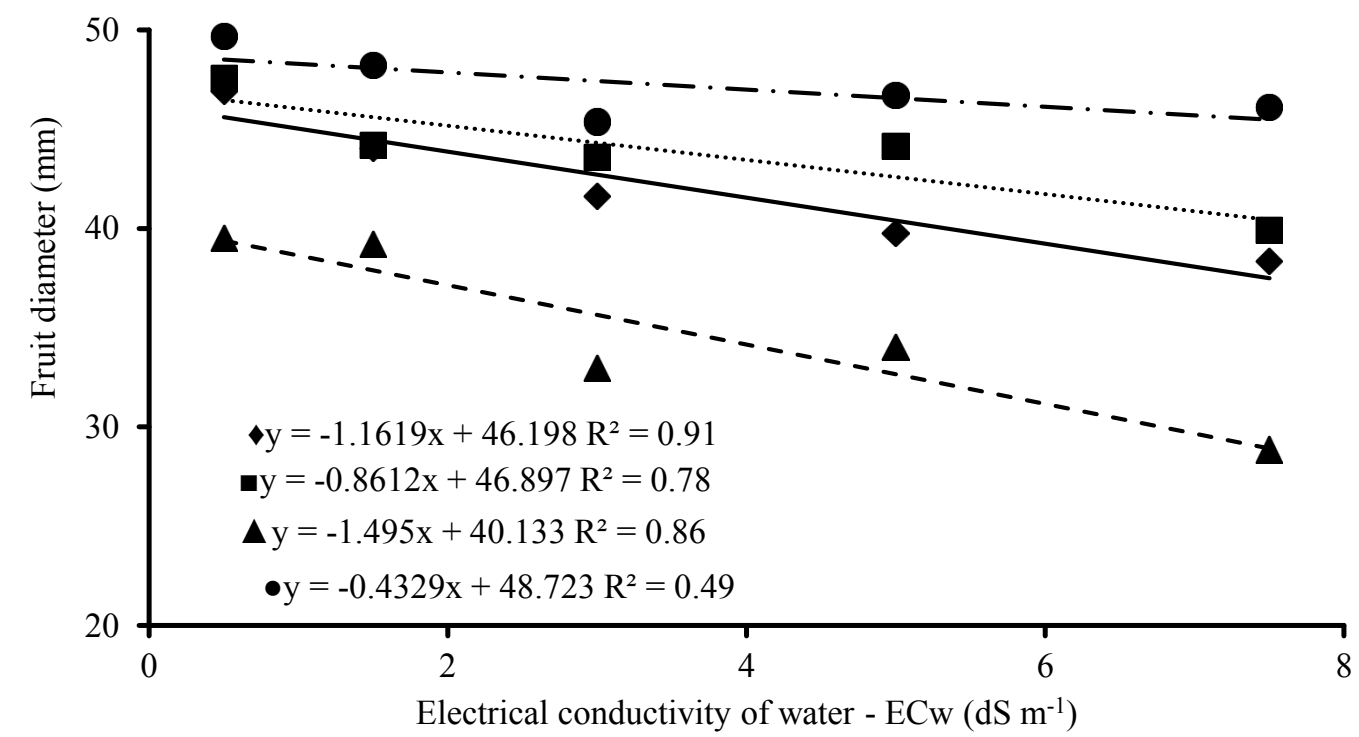

Figure 6. Fruit diameter in bell pepper crop under different levels of salinity in irrigation water and different fertilization regimens; F1 ), F2 ( $\boldsymbol{\square}), \mathrm{F} 3(\boldsymbol{\Delta})$, and F4 ( 
The results reported by Oliveira et al. (2014) of the analysis of the interaction between salinity and nitrogen fertilization in the aubergine crop were contrary to the findings in this study. However, they obtained a similar isolated effect of saline stress, i.e., a reduction in fruit diameter. Dias et al. (2012) observed the same trend in the diameter of yellow passion fruits irrigated with saline water and treated with bovine biofertilizer.

The salts in irrigation water caused a reduction in yield in all study treatments, as shown in Figure 7. However, treatment F1was more effective in mitigating the effect on yield than the other treatments. The superiority of F1 was probably related to the input of nutrients through mineral fertilization, i.e., these essential elements mitigated the displacement of salts $\left(\mathrm{Na}^{+}\right.$and $\left.\mathrm{Cl}^{-}\right)$to the photoassimilates and subsequently to the fruits, thereby providing greater yield.

Another aspect is the short cycle of the bell pepper crop, i.e., the biofertilizer was the only source of nutrients for plants in treatments F1, F2, and F3, and may not have provided sufficient amounts of nutrients to ensure greater yields.

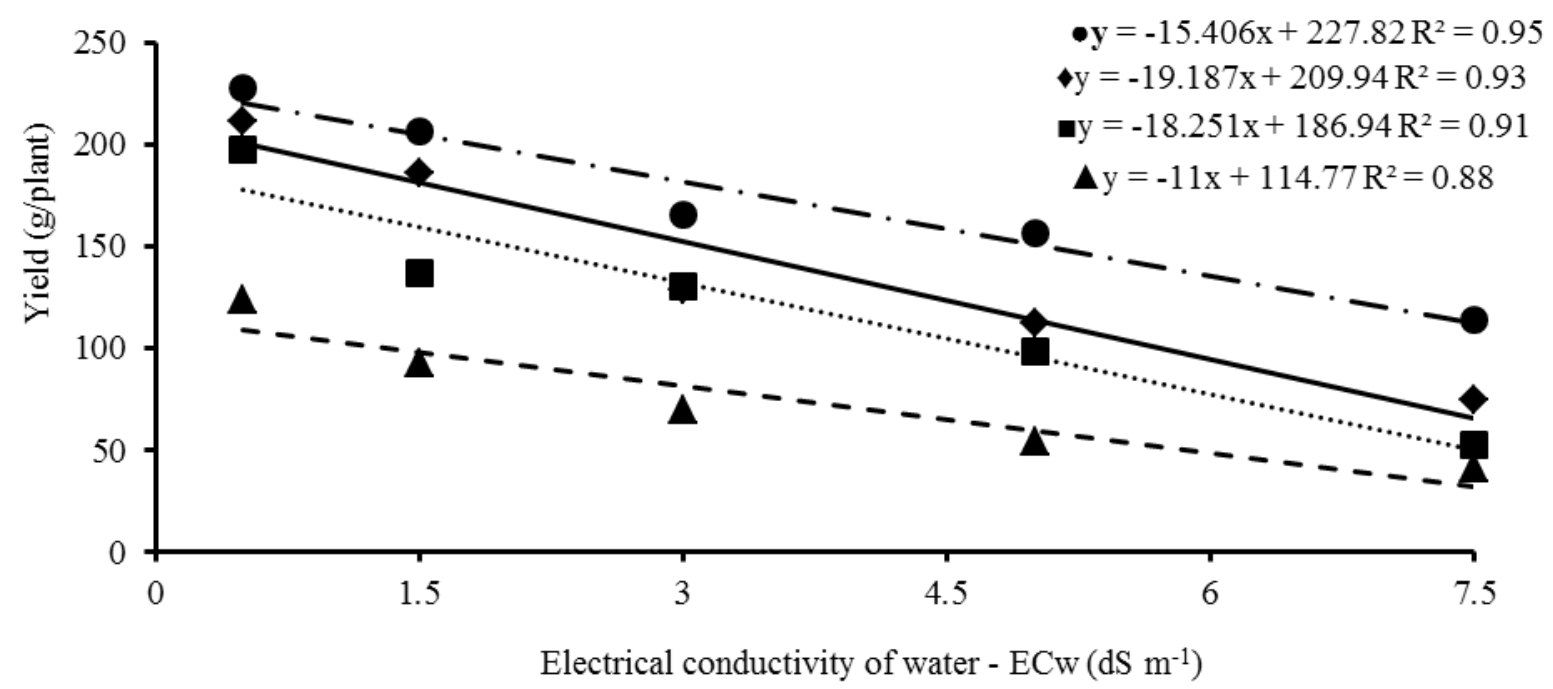

Figure 7. Yield of bell pepper crop under different levels of irrigation watersalinity and different fertilization regimens,

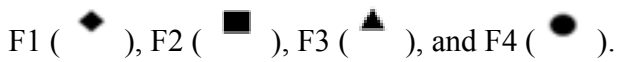

Similar results were obtained by Nunes et al. (2013) in the bell pepper crop grown under nutrient solution with saline water. Moreover, Unlukara, Kurunç, and Cemek(2015) also reported this decreasing effect on the bell pepper crop cultivated in a hydroponic system.

Oliveira et al. (2014) evaluated the interaction between salinity and nitrogen fertilization in the aubergine crop and also observed that only the plants irrigated with water with lower salinity levels responded to nitrogen fertilization. Silva et al. (2013) also demonstrated a positive effect of applying biofertilizer to soil irrigated with saline water on bean crop yield.

\section{CONCLUSIONS}

Treatment F3 (150\% of the recommended dose of an organic fertilizer) was the most effective regimen in mitigating the deleterious effect of saline waste water on the growth of bell peppers cultivated in a semi-hydroponic system, followed by F4 (100\% of the recommended dose of a mineral fertilizer) and
F1 $(50 \%$ of there commended dose of an organic fertilizer).

Treatment F4 $(100 \%$ of the recommended dose of a mineral fertilizer) led to a higher production performance of the bell pepper crop in the semi-hydroponic system irrigated with saline waste water than the other treatments.

\section{REFERENCES}

CAMPOS, V. B.; CAVALCANTE, L. F. Salinidade da água e biofertilizante bovino: efeito sobre a biometria do pimentão. Holos, v. 2. n. 25 , p. 10-20, 2009.

CAVALCANTE, L. F. et al. Irrigação com águas salinas e uso de biofertilizante bovino na formação de mudas de pinhão-manso. Revista Irriga, v. 16, n. 3, p. 288-300, 2011.

DIAS, T. J. et al. Qualidade física e produção do maracujá amarelo em solo combio fertilizante irrigado com águas salinas. Semina, v. 33, sup., p. 
2905-2918, 2012

GUEDES FILHO, D. H. et al. Biometria do girassol em função da salinidade da água de irrigação e da adubação nitrogenada. Revista Brasileira de Agricultura Irrigada, v. 7, n. 5, p. 277-289, 2013.

Guimarães, J. W. A. Produção Orgânica Irrigada e Rentabilidade do Pimentão Amarelo sob diferentes Ambientes e Dosagens de Biofertilizante. 2013. 136 f. Tese (Doutorado em Engenharia Agrícola) - Universidade Federal do Ceará, Fortaleza, 2013.

GOMES, K. R. et al. Irrigação com água salina na cultura do girassol (Helianthusannuus L.) em solo com biofertilizantebovino. Irriga, v. 20, n. 4, p. 680 693, 2015.

INSTITUTO BRASILEIRO DE GEOGRAFIA E ESTATÍSTICA - IBGE. Censo Agropecuário 2016. Disponível em: <http://www.ibge.gov.br/home/ estatistica/economia/agropecuaria/censoagro/ brasil_2006/Brasil_censoagro2006.pdf $>$. Acesso em: 31 de mar de 2016.

LEMOS NETO et al. Análise do crescimento inicial do pimentão submetido a diferentes níveis de salinidade. Enciclopédia Biosfera, Centro Científico Conhecer, v. 8, n. 14; p. 42-50, 2012.

LEONARDO, M. et al. Produção de frutos de pimentão em diferentes concentrações salinas. Irriga, v. 12, n. 1, p. 73-82, 2007.

LIMA, G. S. et al. Aspectos de crescimento e produção da mamoneira irrigada com águas salinas e adubação nitrogenada. Revista Brasileira de Engenharia Agrícola e Ambiental, v. 18, n. 6, p. 615-622, 2014.

MEDEIROS, P. R. F. et al. Tolerância da cultura do tomate à salinidade do solo em ambiente protegido. Revista Brasileira de Engenharia Agrícola e Ambiental, v. 16, n. 1, p. 51-55, 2012.

MERCADO COMUM DO SUL - MERCOSUL.Resolução 142/96, de 13 de dezembro de 1996. Aprova o RegulamentoTécnico MERCOSUL de Identidade e de Qualidade do Pimentão. Disponível em: < < <ttp://www.mercosur.int/msweb/Normas/ normas_web/Resoluciones /PT/96142.pdf $>$. Acesso em: 25 mar. 2016.

MORAES, D. P. et al. Rejeito salino e solução nutritiva em alface cultivada em sistema hidropônico, Magistra, v. 26, n. 3, p. 357-364, 2014.

NASCIMENTO, J. A. M. et al. Efeito da utilização de biofertilizante bovino na produção de mudas de pimentão irrigadas com água salina. Revista Brasileira de Ciências Agrárias, v. 6, n. 2, p. 258264, 2011.

NUNES, R. L. C. et al. Efeitos da salinidade da solução nutritiva na produção de pimentão cultivado em substrato de fibra de coco. Revista Caatinga, v. 26, n. 4, p. 48-53, 2013.

OLIVEIRA, F. A. et al. Interação entre salinidade da água de irrigação e adubação nitrogenada na cultura da berinjela. Revista Brasileira de Engenharia Agrícola e Ambiental, v. 18, n. 5, p. 480-486, 2014.

RUBIO, J. S. et al. Sweet pepper production in substrate in response to salinity, nutrient solution management and training system. Horticultura Brasileira, v. 29, n. 3, p. 275-281, 2011.

SANTOS, E. O. et al. Biomass accumulation and nutrition in micropropagated plants of the banana 'pratacatarina' under biofertilisers. Revista Caatinga, v. 30, n. 4, p. 901-911, 2017.

SEDIYAMA, M. A. N.et al. Rendimento de pimentão em função da adubação orgânica e mineral. Horticultura Brasileira, v. 27, n. 3, p. 294-299, 2009.

SILVA, A. O. et al. Consumo hídrico da rúcula em cultivo hidropôniconft utilizando rejeitos de dessalinizador em Ibimirim-PE. Irriga, v. 17, n. 1, p. 114-125, 2012.

SILVA, F. L. Yield of common figfertigated with bovine biofertilizer in the semiarid region of Ceará. Revista Caatinga, v. 29, n. 2, p. 425-434, 2016.

SILVA, F. L. B. et al. Irrigação com águas salinas e uso de biofertilizante bovino nas trocas gasosas e produtividade de feijão-de-corda. Irriga, v. 18, n. 2, p. 304-317, 2013.

SOARES, T. M. et al. Destinação de águas residuárias provenientes do processo de dessalinização por osmose reserva. Revista Brasileira de Engenharia Agrícola e Ambiental. v. 10, n. 3, p. 730-737, 2006.

SOUSA, G. G. et al. Irrigação com água salobra na cultura do rabanete em solo com fertilizantes orgânicos. Revista Brasileira de Agricultura Irrigada, v. 10, n. 6, p. 1065-1074, 2016.

STEDUTO, P. et al. Crop yield response to water. FAO Irrigation and Drainage Paper 66. Rome, 2012, $505 \mathrm{p}$.

TIVELLI, S.W.; MENDES, F.; GOTO, R. 
Estimativa da área foliar do pimentão cv. Elisa conduzido em ambiente protegido (Capsicumannum L.). In: CONGRESSO BRASILEIRO DE OLERICULTURA, 38., 1997, Manaus. Anais... Brasília: SOB, 1997.

TRANI, P. E.; TIVELli, S. W.; CARRIJO, O. A. Fertirrigação em Hortaliças. Campinas: IAC, 2011. 51 p. (Boletim Técnico, 196).

ÜNLÜKARA, A.; KURUNÇ, A.; CEMEK, B. Green long pepper growth under different saline and water regime conditions and usability of water consumption in plant salt tolerance. Journal of Agricultural Sciences, v. 21, s/n., p. 167-176, 2015. 